\title{
Comparative Proteome Analysis of Silkworm in Its Susceptibility and Resistance Responses to Bombyx mori Densonucleosis Virus
}

\author{
Hui-qing Chen ${ }^{a}$ Qin Yao ${ }^{a}$ Fang Bao ${ }^{a}$ Ke-ping Chen ${ }^{a}$ Xiao-yong Liu ${ }^{a} \quad J u n$ Li $^{a}$ \\ Lin Wang ${ }^{b}$ \\ ${ }^{a}$ Institute of Life Sciences, Jiangsu University, Zhenjiang, and ${ }^{b}$ Beijing Entry-Exit Inspection and Quarantine Bureau, \\ Beijing, PR China
}

\section{Key Words}

Silkworm • Densovirus - Resistance mechanism •

2-D electrophoresis $\cdot$ MALDI-TOF-TOF MS

\begin{abstract}
Bombyx mori densonucleosis virus (BmDNV) is one of the most disastrous viruses in cocoon production. Silkworm resistance to $B m D N V$ has been examined previously using a number of traditional biochemical and molecular techniques. In this study, a near isogenic line, $\mathrm{BC}_{6}$, was constructed to eliminate the difference in inherited background, which has $99.9 \%$ identity with the susceptible strain but carries a resistant gene. We utilized a proteomic approach involving two-dimensional differential gel electrophoresis and mass spectrometry to examine changes in the midgut proteins from the susceptible and resistant silkworm larvae infected with BmDNV. The protein profiles were compared and 9 differentially expressed proteins were identified by mass spectrometry. In the resistant strains, the heat-shock 70-kDa protein cognate, cytochrome P450, vacuolar ATP synthase subunit $B$, arginine kinase, vacuolar ATP synthase subunit $D$ and glutathione $S$-transferase sigma were strongly upregulated and $\alpha$-tubulin was downregulated. Our results imply that these upregulated genes and the downregulated genes might be involved in $B$. mori immune responses against BmDNV-Z infection.

Copyright $\odot 2011$ S. Karger AG, Basel
\end{abstract}

\section{Introduction}

Bombyx mori densovirus (BmDNV), a virus that impacts the sericultural industry by destructive damage throughout the rearing of larvae in many farms, has long been seen as a serious problem. The midgut columnar cells infected by this virus contain hypertrophied nuclei where the virus multiplies. The infected susceptible larvae become flaccid and develop diarrhea as midgut tissue is destroyed, a condition known as flacherie, and finally die $[1,2]$.

$B m D N V$ belongs to Parvoviridae. $B m D N V s$ are classified into two major types, type I and type II, based on their genomic characteristics. BmDNV type II possesses a split genome comprising two types of single-stranded linear DNA molecules. BmDNVs of this type include $B m D N V-2$ (Yamanashi isolate) $[3,4]$ and $B m D N V-Z$ (Zhenjiang isolate) that contains two ssDNA molecules [5]. Li et al. [6] have shown that a recessive gene, nsd-Z, controls non-susceptibility to DNV-Z. This gene is located on chromosome 15 [7] and the closest SSR marker linked to nsd- $Z$ was mapped at a distance of $4.4 \mathrm{cM}$ from nsd-Z $[6,8]$. Although this gene has been mapped with phenotypic or DNA markers, neither of them has been

H.C. and Q.Y. contributed equally to this work.

\section{KARGER}

Fax +4161306 1234

E-Mail karger@karger.ch

www.karger.com
(C) 2011 S. Karger AG, Basel

$0300-5526 / 12 / 0551-0021 \$ 38.00 / 0$

Accessible online at:

www.karger.com/int 


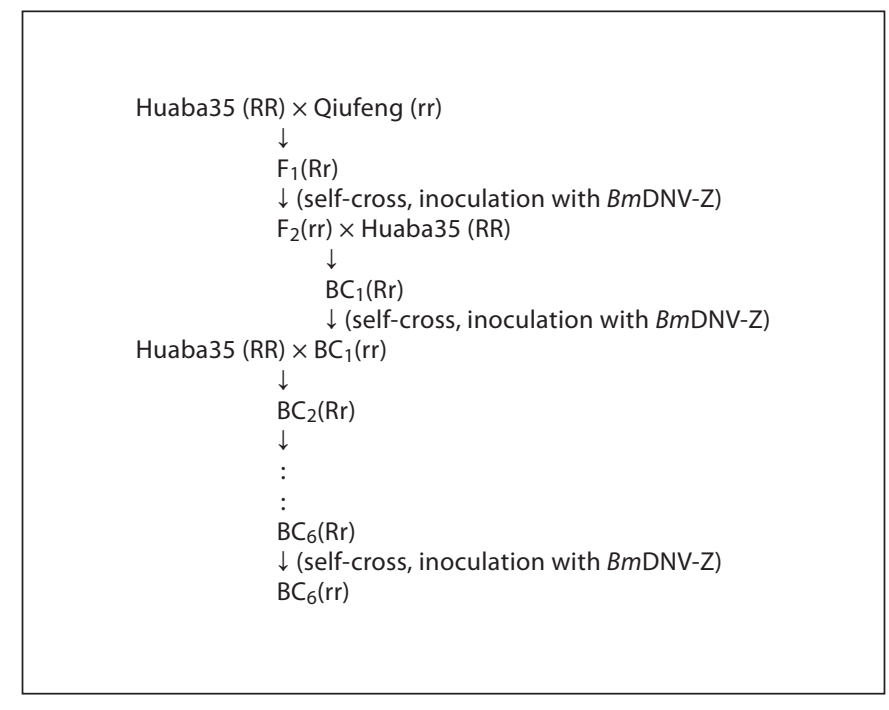

Fig. 1. Establishment of near isogenic lines $\mathrm{BC}_{6} \cdot \mathrm{BC}_{1}$ and $\mathrm{BC}_{2}$ stand for the first and second backcrosses and so forth. $\mathrm{R}=$ Dominant gene; $r=$ recessive gene.

isolated from B. mori yet. The details of the mechanisms by which $B m D N V$ specifically infects its host and the manner in which $B$. mori strains effectively defend themselves against $B m D N V$ infection remain unclear.

The silkworm response upon DNV infection is of particular interest, especially the response of resistant lines in comparison to susceptible lines. Some studies on resistance have been undertaken successfully on the gene and transcription level [9], but few studies have been performed to investigate the silkworm response upon DNV infection on the translation level. Proteomic techniques provide powerful tools for studying $B$. mori stress responses and possible mechanisms of $B$. mori resistance to $B m \mathrm{DNV}-\mathrm{Z}$. Using a two-dimensional gel electrophoresis (2-DE)-based protein separation method, a global protein expression profile can be generated and compared. The objective of this study was to identify differentially expressed proteins between BmDNV-resistant and $B m \mathrm{DNV}$-susceptible strains under infected conditions, as well as describe the possible mechanisms of resistance in B. mori.

\section{Materials and Methods}

\section{Silkworm Strains}

The silkworm strain Qiufeng (nsd-Z/nsd-Z), which is resistant to $B m \mathrm{DNV}-Z$, and Huaba35 strain ( $+n s d-Z /+n s d-Z)$, which is susceptible to $B m \mathrm{DNV}-\mathrm{Z}$, were maintained by single pair matings.
We constructed the near isogenic line $\mathrm{BC}_{6}$, which was obtained by continuously using the females of cyclical backcross parent, Huaba35, to cross the males carrying resistant genes of strain Qiufeng that was used as the donor of resistant genes. First we used Huaba35 to cross the males of strain Qiufeng. Then the $F_{1}$ generation was self-crossed. $B m D N V-Z$ virus was inoculated to larvae of each self-crossed generation to screen the individuals carrying resistant gene. Subsequently, we used the individuals carrying resistant genes to cross the strain Huaba35. The backcrosses were conducted for 6 generations (fig. 1). Thus the $\mathrm{BC}_{6}$ strain also carries the recessive gene (nsd-Z/nsd-Z). In theory, the inherited background of $\mathrm{BC}_{6}$ has $99.9 \%$ identity with Huaba35, the susceptible strain [10].

In order to investigate the mortality of silkworm, DNV-Z was fed to the second instar larvae of three silkworm strains, Huaba35, the near isogenic line $\mathrm{BC}_{6}$ and Qiufeng. For each strain, 100 larvae were taken and the controls were fed with fresh mulberry leaves treated with the same volume of water.

\section{Sample Preparation}

All larvae of three silkworm strains, Huaba35, $\mathrm{BC}_{6}$ and Qiufeng, were raised on fresh mulberry leaves to the fifth instar. For each strain, 15 newly metamorphosed fifth instar larvae were taken and fed with fresh mulberry leaves treated with $0.1 \% \mathrm{BmDNV}$ Z. All of the infected silkworms were checked for DNV by immunoperoxidase staining methods [11].

Midguts of the larvae were extracted, frozen in liquid nitrogen and ground immediately. The samples were directly placed in a lysis buffer consisting of $8 \mathrm{M}$ urea, $4 \%$ CHAPS, $40 \mathrm{~mm}$ Tris- $\mathrm{Cl}$ ( $\mathrm{pH}$ 7.5), $1 \mathrm{~mm}$ EDTA, and $0.2 \%$ BioLyte $3 / 10$ ampholyte. Fresh $1 \mathrm{~mm}$ dithiothreitol (DTT) and a protease inhibitor mixture containing $1 \mathrm{~mm}$ PMSF, $10 \mathrm{mg} / \mathrm{ml}$ leupeptin, $10 \mathrm{mg} / \mathrm{ml}$ pepstatin $\mathrm{A}$, and 10 $\mathrm{mg} / \mathrm{ml}$ aprotinin were added to buffers prior to use. Finally, the sample was centrifuged under $12,000 \mathrm{rpm}, 4^{\circ}$ for $30 \mathrm{~min}$. Protein concentrations in the samples were determined by an RC/DCTM protein assay after rehydration. All chemicals and kits were supplied by BioRad unless otherwise specified.

\section{Two-Dimensional Gel Electrophoresis}

The manufacturer's recommended volume $(185 \mu \mathrm{l}$, containing approx. $600 \mu \mathrm{g}$ proteins) of recovered proteins was applied to 11cm IPG strips (Immobiline DryStrips), pH 4-7, for overnight active rehydration. The IPG strips were then subjected to isoelectric focusing using a Protean IEF Cell. Focusing was performed as follows: $250 \mathrm{~V}$ for $30 \mathrm{~min}, 1,000 \mathrm{~V}$ for $30 \mathrm{~min}, 8,000 \mathrm{~V}$ for $4 \mathrm{~h}$ and then up to $40,000 \mathrm{~V}$ for approximately $3 \mathrm{~h}$. Current did not exceed $50 \mathrm{~mA}$ per strip.

After isoelectric focusing, the IPG strips were equilibrated for 15 min in equilibration buffer I ( 6 M urea, 2\% SDS, 0.375 M Tris$\mathrm{HCl}(\mathrm{pH} 8.8), 20 \%$ glycerol and $2 \%(\mathrm{w} / \mathrm{v})$ DTT) followed by $15 \mathrm{~min}$ in buffer II (same as buffer I but containing $2.5 \%$ iodacetamide instead of DTT).

For the second dimension, IPG strips were placed across a Criterion Precast Gel and overlaid with agarose. Electrophoresis was run with a constant voltage, $120 \mathrm{~V}$, until the bromphenol blue dye front had completely migrated out of the bottom of the gel.

Gels were fixed overnight in a solution of $50 \%$ ethanol and $10 \%$ acetic acid, stained with Coomassie (BioRad) for at least $1 \mathrm{~h}$ and washed in water. Three independent samples were analyzed for each treatment. 


\section{Image Analysis}

Gel images were scanned with a BioRad SanMaker 9700XL imaging system and image analysis was performed using PDQuest (version 7.2.0; BioRad). The differential spots were first compared between Huaba35 and $\mathrm{BC}_{6}$. Only the spots in $\mathrm{BC}_{6}$, which are consistent with Qiufeng, were chosen. Protein spots detection and matching were performed automatically and matches reviewed manually and edited where necessary in order to remove false spots, include missed spots, and to distinguish spots within clusters. The Total Quantity in Valid Spots normalization method was used to compensate for any non-expressionrelated variations in spot intensity. Only those spots that were reproducible in all three biological replicates were included in the analysis. Student's t test $(\mathrm{p}<0.05)$ was used to identify differentially expressed spots (at least twofold change in expression).

\section{In-Gel Digest}

Bands were trimmed as close as possible to minimize background polyacrylamide material. The gels were washed in 50\% methanol and 5\% acetic acid for several hours. The gel bands were dried with acetonitrile and reconstituted with DTT solution to reduce the cysteines. Iodoacetamide was added to alkylate the cysteines, and the gel was washed again with cycles of acetonitrile and ammonium bicarbonate. Trypsin was added and digested at room temperature overnight. After they were dried in a SpeedVac for $10 \mathrm{~min}$, peptide extraction was performed with $10 \mathrm{ml}$ of $1 \%$ TFA. Extracted peptides were directly applied onto a target (AnchorChip $^{\mathrm{TM}}$; Bruker Daltonics, Bremen, Germany) that was loaded with $\alpha$-cyano-4-hydroxycinnamic acid matrix thin layer.

\section{MALDI-TOF/TOF Mass Spectrometry}

Protein spots that were found to have interesting patterns of differential expression in the susceptible and resistant strains 2-D maps were subjected to identification of proteins using peptide mass fingerprinting. Mass spectrometry (MS) measurements were carried out on an ultraflex II TOF-TOF (Bruker Daltonics) with delayed ion extraction. The instrument was operated in the reflector for MALDI-TOF peptide mass fingerprint mode for MALDI-TOF/TOF with a fully automated mode using the FlexControl $^{\mathrm{TM}}$ software. An accelerating voltage of $25 \mathrm{kV}$ was used for PMF and mass spectra were obtained in a mass range of 5006,000 Da. External calibration was performed with Peptide Mass Standard kit (Perspective Biosystems). The matrix and the autolytic peaks of trypsin served as internal standards for mass calibration. After MS acquisition, the six strongest peptides per spot were selected automatically for the analysis.

\section{Protein Identification and Database Searching}

Protein identification using peptide mass fingerprinting was performed by the MASCOT search engine (http://www.matrixscience.com) against the NCBI protein database and Chinese $B$. mori genome database (http://silkworm.genomics.org.cn/). Mass fingerprints were compared with known proteins from $B$. mori and Drosophila melanogaster as well as from other insects and non-redundant protein databases. Identification criteria were based on the number and coverage of matched peptides. The following parameters were used in all searches: the maximum number of missed cleavages allowed, 1; the mass tolerance, $0.2 \mathrm{Da}$; minimum peptides required to match, 4 , and the monoisotopic masses of observation peaks were used to match the calculated

Midgut Protein, Susceptible and Resistant

Silkworm Strains and BmDNV Infection
Table 1. Results of inoculation of silkworm larvae with BmDNV$\mathrm{Z}$ and its control

\begin{tabular}{llccc}
\hline $\begin{array}{l}\text { Treatment/ } \\
\text { strain }\end{array}$ & $\begin{array}{l}\text { Number } \\
\text { inoculated }\end{array}$ & $\begin{array}{l}\text { Number infected } \\
\text { with BmDNV-Z }\end{array}$ & $\begin{array}{l}\text { Survi- } \\
\text { vors, } \mathrm{n}\end{array}$ & $\begin{array}{l}\text { Incidence of } \\
\text { disease, \% }\end{array}$ \\
\hline $\begin{array}{l}\text { Inoculation } \\
\quad \text { Huaba35 }\end{array}$ & 100 & 98 & 2 & 98 \\
$\quad$ BC $_{6}$ & 100 & 0 & $97^{1}$ & 0 \\
$\quad$ Qiufeng & 100 & 0 & $96^{1}$ & 0 \\
Controls & & & 96 & 6 \\
$\quad$ Huaba35 & 100 & 4 & $97^{1}$ & 0 \\
BC $_{6}$ & 100 & 0 & 100 & 0 \\
Qiufeng & 100 & 0 & & \\
\hline
\end{tabular}

${ }^{1}$ The number of survivors decreased because some were infected with other diseases.

monoisotopic fragment masses for protein identification. Possible covalent modifications considered in the search procedure were carbamidomethylation of cysteine, conversion of peptide N-terminal glutamine to pyroglutamate, oxidation of methionine, and acetylation of protein $\mathrm{N}$-terminus.

\section{Results}

\section{Resistance Identification of Huaba35, the Near}

Isogenic Line $\mathrm{BC}_{6}$ and Qiufeng

For each strain, 100 second instar larvae were taken and fed with $0.1 \% \mathrm{BmDNV}-\mathrm{Z}$, and the controls were treated with the same volume of water. Normally, silkworms that are susceptible to $B m D N V-Z$ develop very slowly and cannot survive through the third instar. The incidence of disease investigation suggested that the average incidence of Huaba35 is $98 \%$, and the others are all zero (table 1). This is consistent with previous results showing that resistance to DNV-Z is recessive [1].

\section{Protein Differences between Susceptible and Resistant Strains}

To compensate the variability of gel electrophoresis, three replicate gels were run for each silkworm strain. Therefore, a total of 9 gels in three groups were subject to statistical analysis using PDQuest software. Based on an automated spot-detection algorithm provided by $\mathrm{PD}$ Quest, means of $350 \pm 3,360 \pm 2.5$, and $365 \pm 2$ protein spots were detected in the gels of Huaba35, $\mathrm{BC}_{6}$, and Qiufeng, respectively (fig. 2).

Since $\mathrm{BC}_{6}$ has a genetic background similar to Huaba35, comparison of the location and volumes associated with each spot revealed that the level of the most midgut 

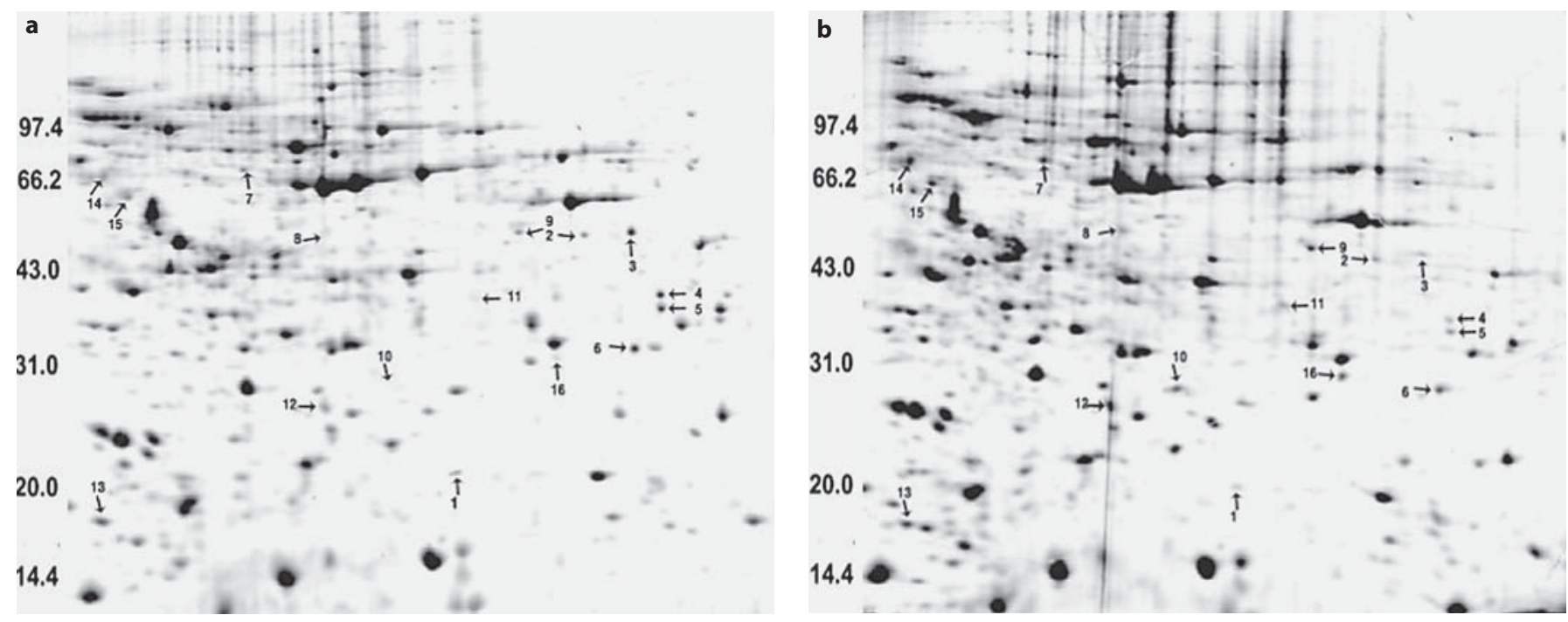

Fig. 2. 2-D electrophoresis maps of midgets from a Huaba35, b $\mathrm{BC}_{6}$ and $\mathbf{c}$ Qiufeng. Proteins were separated by isoelectric focus-

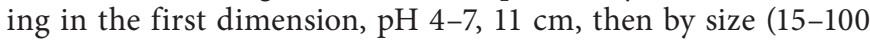
$\mathrm{kDa}$ ) in the second dimension and stained with Coomassie blue. Maps were analyzed with PDQuest software. Selected spots were numbered 1-16.

proteins remains virtually unchanged in the susceptible strain Huaba35 and the near isogenic line $\mathrm{BC}_{6}$. Those spots that were only consistent regulated between $\mathrm{BC}_{6}$ and Qiufeng but opposite to Huaba35 were identified. Comparison of 2-DE images from three biological replicates indicated there were both qualitative and quantitative differences between protein profiles from Huaba35 and $\mathrm{BC}_{6}$. Sixteen spots of 350 total spots in Coomassiestained samples showed twofold or higher differences between the two samples.

Only the relatively abundant proteins, those stained with Coomassie and having at least a twofold difference between susceptible and resistant strains in all 3 replicates, were selected for identification. These spots, 6 from

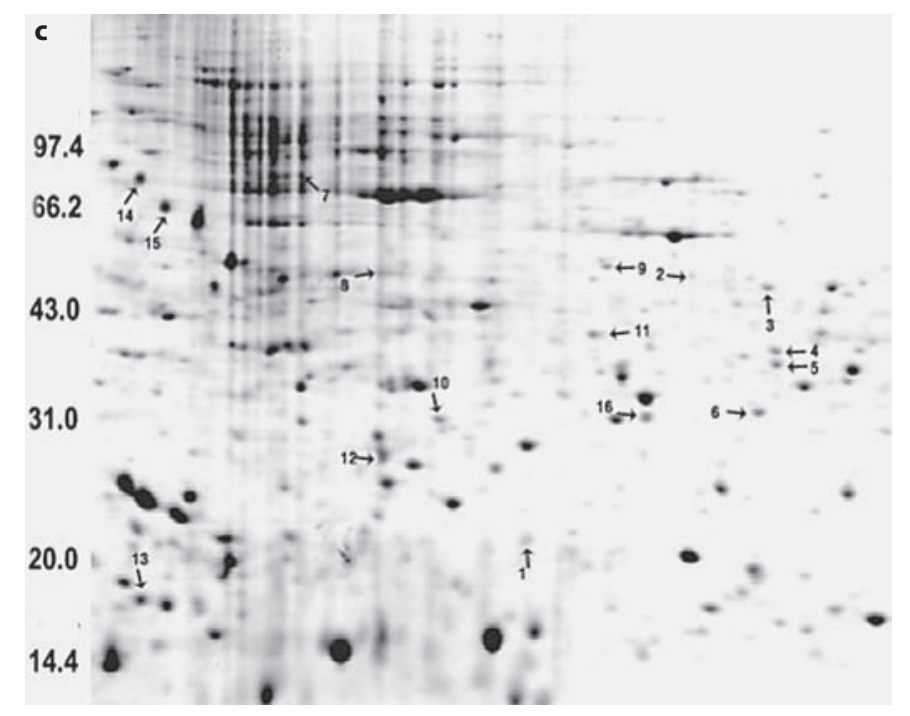

a susceptible strain and 10 from a resistant one, are indicated in figure 2.

\section{Identification of Differential Proteins}

Most protein peptide mass fingerprints did not match entries in the public databases indicating that there are considerable variations of the trypsin hydrolytic peptide masses for homologous proteins among organisms. Consequently, only those proteins identified are indicated by arrows in figure 2 and are listed in table 2 . The expression levels of 16 of the 350 proteins were significantly different in the susceptible and resistant insects. Samples of resistant strains contained 1 unique and 9 upregulated protein spots, and 6 downrequlate protein spots. Spot volume 
Table 2. Identification of resistance-related midgut proteins in B. mori

\begin{tabular}{|c|c|c|c|c|c|}
\hline Spot No. & Accession No. & Species & Protein ID & Predicted mass, $\mathrm{kDa} / \mathrm{p} I$ & Mowse score $^{1}$ \\
\hline \multicolumn{6}{|c|}{ Downregulated proteins } \\
\hline 1 & 17136564 & D. melanogaster & $\alpha$-tubulin & $49,876 / 5.00$ & 94 \\
\hline $2-6$ & - & - & unknown & - & - \\
\hline \multicolumn{6}{|c|}{ Upregulated proteins } \\
\hline 7 & 112984012 & B. mori & heat-shock $70-\mathrm{kD}$ protein cognate & $73,166 / 5.13$ & 137 \\
\hline 8 & 157111182 & Aedes aegypti & cytochrome P450 & $58,309 / 8.5$ & 83 \\
\hline 9 & 148298717 & B. mori & vacuolar ATP synthase subunit B & $54,667 / 5.25$ & 89 \\
\hline 10 & 112983926 & B. mori & arginine kinase & $40,308 / 5.87$ & 190 \\
\hline 12 & 112983926 & B. mori & arginine kinase & $39,966 / 5.87$ & 95 \\
\hline 13 & 112983926 & B. mori & arginine kinase & $39,966 / 5.87$ & 96 \\
\hline 14 & 114053249 & B. mori & vacuolar ATP synthase subunit D & $27,443 / 9.59$ & 85 \\
\hline 16 & 160333678 & B. mori & glutathione S-transferase sigma & $23,382 / 5.85$ & 74 \\
\hline $11 / 15$ & - & - & unknown & - & - \\
\hline
\end{tabular}

${ }^{1}$ Mowse score $>74$ indicates identity or extensive homology $(\mathrm{p}<0.05)$; higher scores indicate higher confidence of identity.

comparisons of the selected spots (fig. 3) indicated pronounced differences in the amounts of specific proteins present in the midgut of susceptible and resistant larvae. The proteins identified by peptide mass fingerprinting include $\alpha$-tubulin, heat-shock $70-\mathrm{kDa}$ protein cognate, cytochrome P450, vacuolar ATP synthase subunit B, arginine kinase, vacuolar ATP synthase subunit D and glutathione S-transferase sigma (table 2).

\section{Discussion}

In this study, two non-susceptible strains displaying significant resistance to $B m D N V-Z$ as well as a susceptible strain were analyzed using 2-DE in combination with MALDI-TOF MS. The protein database for B. mori and other lepidopterous insects is poor, thus the task of identifying the proteins with certainty remains a challenge. In this study, nine of these proteins have been identified, which may play a role in $B m D N V-Z$ resistance. Most spots in the gel figures displayed a reasonable correlation of the theoretical $\mathrm{p} I$ and $\mathrm{M}_{\mathrm{r}}$ values with the experimental data.

Insects are among the earliest and most successful group of animals that exist in a myriad of environments where the potential for infection by microorganisms and parasites is great. Insects have also demonstrated considerable ability to develop resistance to viruses. Though cellular reactions like phagocytosis, nodulation and encapsulation and humoral reaction through secretion of antibacterial proteins are known for fungus and bacterial invaders, little is known about insect defense against insect virus infection [12]. Compared to vertebrates, insects do not possess the ability to produce antibodies (immunoglobulins) and do not use immunoglobulin as recognition molecules in the classical sense, against foreign antigens and hence antigenic memory appears to be lacking. Insects possess innate immunity which is characterized by non-specific immune reactions against foreign materials. Non-specific immunity consists of structural and passive barriers like cuticle, gut physicochemical properties, and peritrophic membrane.

The $B m \mathrm{DNV}-\mathrm{Z}$ infection starts when the larva ingests the virions; the virions multiply only in the nuclei of the columnar cells of the larval midgut epithelium [13]. The role of the peritrophic membrane in the resistance mechanism against $B m \mathrm{DNV}$ has not been demonstrated, although this midgut cellular structure is considered an important gut barrier against insect viral infection [14]. The midgut $\mathrm{pH}$ may affect virus activity by changing and altering the rate and location of virion release in the midgut lumen [15]. Vacuolar ATP synthases (V-ATPases) are phylogenetically widespread, highly conserved, multisubunit proton pumps [16]. This enzyme is present in the plasma membrane of columnar cells and is the sole energizer for secretion and absorption by serving as an $\mathrm{H}^{+} / \mathrm{K}^{+}$ transporter across the insect midgut epithelium [17]. In our study, the resistant strains contained increased VATPase. Perhaps an increased V-ATPase expression may rapidly acidifies the epithelial cells to a low $\mathrm{pH}$ level, 


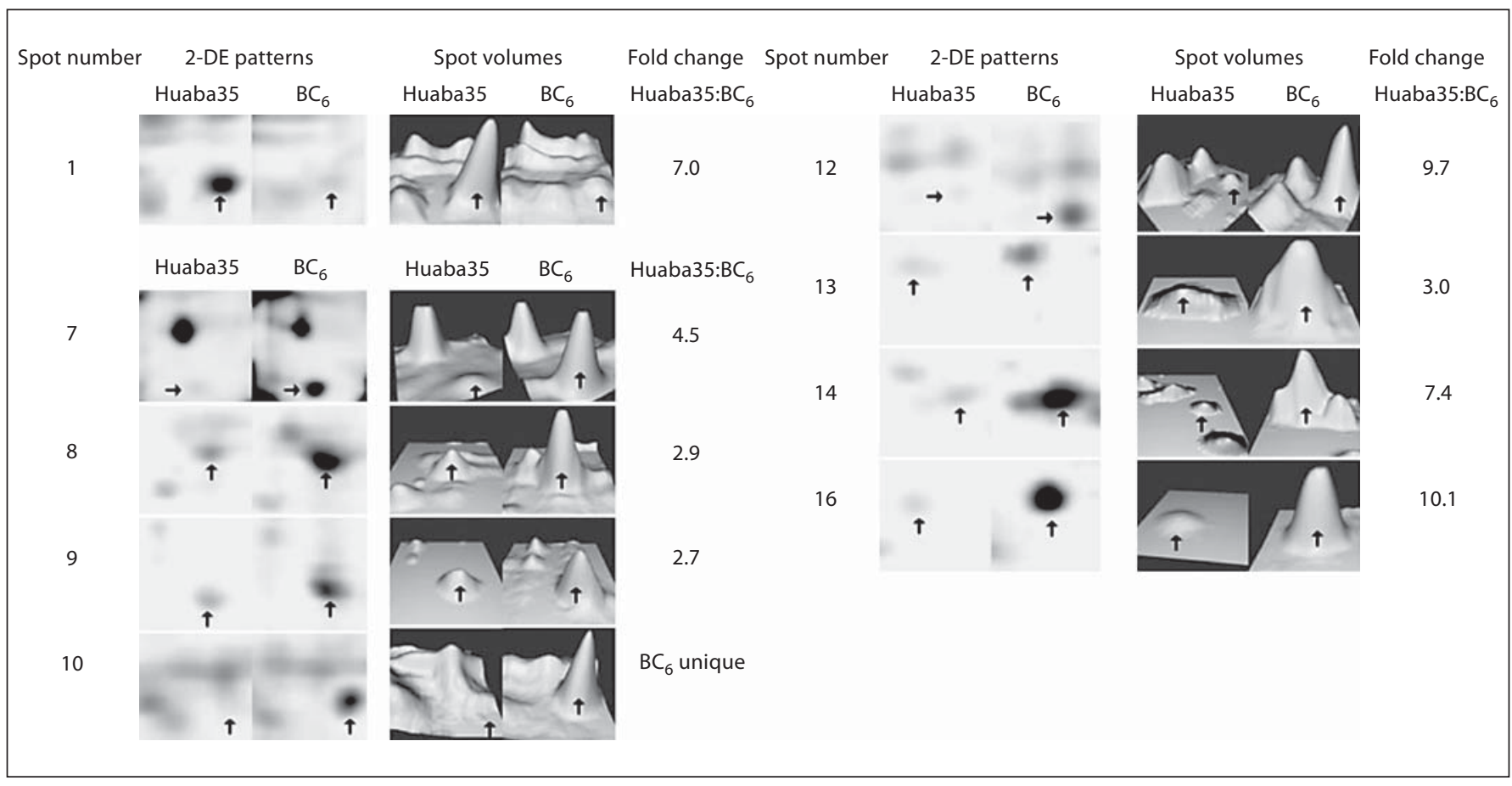

Fig. 3. Selected area of 2-D gels and corresponding spot volumes for selected spots identified in the Huaba35 and Qiufeng strains. Image pairs and detection of protein spots with relative spot volumes were achieved using PDQuest software (BioRad). 2-DE = 2-D electrophoresis.

which accompanies the BmDNV-resistant state of the silkworm larva, reflects the $\mathrm{pH}$ level across the midgut epithelium that may be necessary to combat the viruses and consequently to maintain resistance at the tissue level.

One of the major proteins that were expressed differentially between the susceptible strain and the resistant one was chaperone, heat-shock $70-\mathrm{kDa}$ protein cognate (hsc70). hsc70 is a constitutive member of the heat-shockinduced hsp70 protein family that functions in normal cellular physiology. The proteins in this family are highly conserved nucleocytoplasmic ATPases which have been associated to a number of functions, including protein folding, translocation across biological membranes, and assembly and disassembly of oligomeric complexes. In response to different stress conditions, these proteins prevent the formation of protein aggregates by stabilizing unfolded intermediates which are subsequently refolded to the native state or degraded [18-20]. hsc70 and other heat-shock proteins have been reported to be present on the surface of tumor cell lines [21] and in cells infected with viruses [22], as well as in mammalian spermatogenic cells [4], monocytes and B cells [23]. hsc70 has been detected more abundant on the surface of the rotavirusresistant cells than the susceptible cells [24]. It has been shown that hsc70 protein was able to block rotavirus infectivity in a dose-dependent manner when preincubated with the viruses before infection. In this study, hsc70 was upregulated in the resistant strains, which further indicates that differential expression of hsc70 is correlated with resistance to $B m \mathrm{DNV}$.

The amount of glutathione S-transferase (GST) and was 10.1 times higher in the resistant strain, suggesting an increase in the use of reduced GSH and possible changes in the redox environment in the midgut epithelium of the resistant larva. GSTs are a family of phase II enzymes that catalyze the conjugation of glutathione to endogenous and exogenous electrophilic substrates. This converts these chemicals into water-soluble, less toxic metabolites that can be easily excreted from the cell. GSTs therefore play an important role in the detoxification of many potentially harmful compounds [25]. The presence of cytochrome p450 with 7.4 times higher in resistant strains nicely supports the previous evidence that abundance of GSTs have been found in chemical insecticideresistant insect strains together with increased levels of 
cytochrome p450s that are responsible for metabolic resistance to insecticides $[26,27]$.

Comparison of midgut proteins in both susceptible and resistant larvae also revealed a noticeable increase in the level of arginine kinase (AK). Previously, overexpression of the Trypanosoma cruzi improves the ability of the transfectant cells to grow and resist nutritional and $\mathrm{pH}$ stress conditions [28]. AK plays an important role as a regulator of energetic reserves and cell growth by catalyzing the reversible transfer of the phosphate group from MgATP to arginine, leading to production of phosphoarginine and MgADP [29]. Canonaco et al. [30] reported that recombinant yeast expressing AK showed improved resistance under stress challenges that drain cellular energy, which were transient $\mathrm{pH}$ reduction and starvation. Probably the increase in the level of AK in the resistant insects is required to replenish the energy in the resistant larval midgut cells that have a relatively higher utilization to adjust to the extreme conditions than the susceptible strain.

The tubulin gene family consists of six distinct but highly conserved subfamilies, $\alpha-, \beta-, \gamma_{-}, \delta$-, $\varepsilon$-, and $\zeta_{\text {-tu- }}$ bulins [31]. Heterodimers of these proteins are the primary constituents of microtubules, which are the main components of the cell cytoskeleton [32]. Microtubules have long been implicated in viral nucleocapsid movement since their close association was first observed by electron microscopy $[33,34]$. In the previous studies, the involvement of microtubules in virus transport has been reported for a number of viruses [35-38]. In addition, quite a few specific viral proteins that interact directly with microtubules or with microtubule motor proteins have also been identified [39-42]. Previous studies indicated that virus could utilize actin microfilaments of the host for transport to the plasma membrane of infected cells $[43,44]$. The decrease expression of $\alpha$-tubulin in the resistant strain might inhibit the infection cycle of
$B m \mathrm{DNV}-\mathrm{Z}$ in the host, which includes viral assembly, budding, and maturation of progeny virions. As we know, the antiviral mechanism occurring in resistant B. mori strains is not due to resistance against $B m D N V-Z$ invasion, but due to the inhibition of $B m \mathrm{DNV}-\mathrm{Z}$ proliferation in larval midgut cells. The pathways involved in these reactions are currently unclear. Our data provide a global view of host responses to viral infection and insights for further investigation of the complex interactions between $B m \mathrm{DNV}-\mathrm{Z}$ and its host, $B$. mori.

Peptide mass fingerprinting, which involves MS coupled with bioinformatics and relies on current databases, is a useful proteomic technique for protein identification. With increased availability of genome information and predicted proteomes of insects, a comprehensive understanding of the resistant state of insects and their genomic and proteomic expression profiles will be facilitated. Furthermore, comparative proteomic analysis of susceptible and resistant insects should help understand how insects adapt to or resist environmental challenges. One of the drawbacks associated with the use of 2-DE is that the identities of some of the differentially expressed proteins seen in the present study remain unknown. This may have been the absence of protein information in the database. Although we were unable at this time to obtain specific antibodies to verify all of the differentially expressed proteins that we identified, we have described several targets that warrant further investigation utilizing functional studies.

\section{Acknowledgements}

This work was supported by the National High Technology Research and Development Program of China (No. 2008AA10Z145) and the National Natural Science Foundation of China (No. 30871826).

\section{References}

1 Watanabe H: Resistance of the silkworm, Bombyx mori, to viral infections. Agric Ecosyst Environ 1986;15:131-139.

$\checkmark 2$ Watanabe H, Maeda S: Genetically determined nonsusceptibility of the silkworm, Bombyx mori to infection with a densonucleosis virus. J Invertebr Pathol 1981;38:370373.
3 Bando $\mathrm{H}$, Choi $\mathrm{H}$, Ito Y, Nakagaki M, Kawase S: Structural analysis on the single-stranded genomic DNAs of the virus newly isolated from silkworm: the DNA molecules share a common terminal sequence. Arch Virol 1992;124:187-193.

-4 Boulanger J, Faulds D, Eddy EM, Lingwood CA: Members of the 70-kDa heat-shock protein family specifically recognize sulfoglycolipids: role in gamete recognition and mycoplasma-related infertility. J Cell Physiol 1995; 165:7-17.
5 Wang YJ, Yao Q, Chen KP, Wang Y, Lu J, Han $\mathrm{X}$ : Characterization of the genome structure of Bombyx mori densovirus (China isolate). Virus Genes 2007;35:103-108.

6 Li M, Guo Q, Hou C, Miao X, Xu A, Guo X, Huang Y: Linkage and mapping analyses of the densonucleosis non-susceptible gene $n s d-Z$ in the silkworm Bombyx mori using SSR markers. Genome 2006;49:397-402. 
7 Kadono-Okuda K: Densovirus resistance in Bombyx mori; in Goldsmith MR, Marec F (eds): Molecular Biology and Genetics of the Lepidoptera. Boca Raton, CRC Press, 2009, pp 337-346.

8 Li M, Hou C, Zhao Y, Xu A, Guo X, Huang Y: Detection of homozygosity in near isogenic lines of non-susceptible to Zhenjiang strain of densonucleosis virus in silkworm. Afr J Biotechnol 2007;6:1629-1633.

-9 Chen KP, Chen HQ, Tang XD, Yao Q, Wang LL, Han X: Bmpkci is highly expressed in a resistant strain of silkworm (lepidoptera: Bombycidae): implication of its role in resistance to BmDNV-Z. Eur J Entomol 2007;104: 369-376.

10 Bao YY, Li MW, Zhao YP, Ge JQ, Wang CS, Huang YP, Zhang CX: Differentially expressed genes in resistant and susceptible Bombyx mori strains infected with a densonucleosis virus. Insect Biochem Mol Biol 2008;38:853-861.

-11 Kurstak E: Progress in enzyme immunoassays: production of reagents, experimental design, and interpretation. Bull World Health Organ 1985;63:793-811.

12 Narayanan K: Insect defence: its impact on microbial control of insect pests. Curr Sci 2004;86:800-814.

13 Garzon S, Kurstak E: Ultrastructural studies on the morphogenesis of the densonucleosis virus parvovirus. Virology 1976;70:517-531.

$\checkmark 14$ Eisemann $\mathrm{CH}$, Binnington KC: The peritrophic membrane: its formation, structure, chemical composition and permeability in relation to vaccination against ectoparasitic arthropods. Int J Parasitol 1994;24:15-26.

15 Keating ST, Schultz JC, Yendol WG: The effect of diet on gypsy moth (Lymantria dispar) larval midgut $\mathrm{pH}$, and its relationship with larval susceptibility to a baculovirus. J Invert Pathol 1990;56:317-326.

16 Nishi T, Forgac M: The vacuolar $\left(\mathrm{H}^{+}\right)$ATPases - nature's most versatile proton pumps. Nat Rev Mol Cell Biol 2002;3:94-103.

17 Dow JA, Davies SA, Guo Y, Graham S, Finbow ME, Kaiser K: Molecular genetic analysis of V-ATPase function in Drosophila melanogaster. J Exp Biol 1997;200:237-245.

18 Hartl FU: Molecular chaperones in cellular protein folding. Nature 1996;381:571-579.

$\checkmark 19$ Mayer MP, Bukau B: Hsp70 chaperone systems: diversity of cellular functions and mechanism of action. Biol Chem 1998;379: 261-268.
20 Morimoto RI, Kline MP, Bimston DN, Cotto JJ: The heat-shock response: regulation and function of heat-shock proteins and molecular chaperones. Essays Biochem 1997;32:1729.

21 Multhoff G, Hightower LE: Cell surface expression of heat-shock proteins and the immune response. Cell Stress Chaperones 1996;1:167-176.

-22 Brenner BG, Wainberg MA: Heat-shock protein-based therapeutic strategies against human immunodeficiency virus type 1 infection. Infect Dis Obstet Gynecol 1999;7:8090.

23 Manara GC, Sansoni P, Badiali-De Giorgi L, Gallinella G, Ferrari C, Brianti V, Fagnoni FF, Ruegg CL, De Panfilis G, Pasquinelli G: New insights suggesting a possible role of a heat-shock protein $70-\mathrm{kD}$ family-related protein in antigen processing/presentation phenomenon in humans. Blood 1993;82: 2865-2871.

-24 Guerrero CA, Bouyssounade D, Zarate S, Isa P, Lopez T, Espinosa R, Romero P, Mendez E, Lopez S, Arias CF: Heat-shock cognate protein 70 is involved in rotavirus cell entry. J Virol 2002;76:4096-4102.

25 Hayes JD, Pulford DJ: The glutathione Stransferase supergene family: regulation of GST and the contribution of the isoenzymes to cancer chemoprotection and drug resistance. Crit Rev Biochem Mol Biol 1995;30: 445-600.

26 Daborn PJ, Yen JL, Bogwitz MR, Le Goff G, Feil E, Jeffers S, Tijet N, Perry T, Heckel D, Batterham P, Feyereisen R, Wilson TG, French-Constant RH: A single p450 allele associated with insecticide resistance in Drosophila. Science 2002;297:2253-2256.

27 Ranson H, Claudianos C, Ortelli F, Abgrall C, Hemingway J, Sharakhova MV, Unger MF, Collins FH, Feyereisen R: Evolution of supergene families associated with insecticide resistance. Science 2002;298:179-181.

28 Pereira CA, Alonso GD, Ivaldi S, Silber AM, Alves MJ, Torres HN, Flawia MM: Arginine kinase overexpression improves Trypanosoma cruzi survival capability. FEBS Lett 2003; 554:201-205.

29 Ellington WR: Evolution and physiological roles of phosphagen systems. Annu Rev Physiol 2001;63:289-325.

30 Canonaco F, Schlattner U, Pruett PS, Wallimann T, Sauer U: Functional expression of phosphagen kinase systems confers resistance to transient stresses in Saccharomyces cerevisiae by buffering the ATP pool. J Biol Chem 2002;277:31303-31309.
31 McKean PG, Vaughan S, Gull K: The extended tubulin superfamily. J Cell Sci 2001;114: 2723-2733.

-32 Jordan MA, Wilson L: Microtubules as a target for anticancer drugs. Nat Rev Cancer 2004;4:253-265.

33 Granados RR, Lawler KA: In vivo pathway of Autographa californica baculovirus invasion and infection. Virology 1981;108:297-308.

34 Luftig RB, Weihing RR: Adenovirus binds to rat brain microtubules in vitro. J Virol 1975; 16:696-706.

- 35 Carter GC, Rodger G, Murphy BJ, Law M, Krauss O, Hollinshead M, Smith GL: Vaccinia virus cores are transported on microtubules. J Gen Virol 2003;84:2443-2458.

-36 Chen HQ, Chen KP, Yao Q, Guo ZJ, Wang LL: Characterization of a late gene, ORF67 from Bombyx mori nucleopolyhedrovirus. FEBS Lett 2007;581:5836-5842.

-37 Funk A, Mhamdi M, Lin L, Will H, Sirma H Itinerary of hepatitis B viruses: Delineation of restriction points critical for infectious entry. J Virol 2004;78:8289-8300.

- 38 Sodeik B, Ebersold MW, Helenius A: Microtubule-mediated transport of incoming herpes simplex virus 1 capsids to the nucleus. J Cell Biol 1997;136:1007-1021.

39 Alonso C, Miskin J, Hernaez B, FernandezZapatero P, Soto L, Canto C, RodriguezCrespo I, Dixon L, Escribano JM: African swine fever virus protein p54 interacts with the microtubular motor complex through direct binding to light-chain dynein. J Virol 2001;75:9819-9827.

-40 Martin A, O’Hare P, McLauchlan J, Elliott G: Herpes simplex virus tegument protein VP22 contains overlapping domains for $\mathrm{cy}$ toplasmic localization, microtubule interaction, and chromatin binding. J Virol 2002;76: 4961-4970.

41 Ogino T, Iwama M, Ohsawa Y, Mizumoto K: Interaction of cellular tubulin with Sendai virus $M$ protein regulates transcription of viral genome. Biochem Biophys Res Commun 2003;311:283-293.

42 Ward BM, Moss B: Vaccinia virus A36R membrane protein provides a direct link between intracellular enveloped virions and the microtubule motor kinesin. J Virol 2004; 78:2486-2493.

43 Rey O, Canon J, Krogstad P: HIV-1 Gag protein associates with $\mathrm{F}$-actin present in microfilaments. Virology 1996;220:530-534.

44 Liu B, Dai R, Tian CJ, Dawson L, Gorelick R, Yu XF: Interaction of the human immunodeficiency virus type 1 nucleocapsid with actin. J Virol 1999;73:2901-2908. 